\title{
RYTMICKÉ CÍTENIE V SCÉNICKOM DIELE Estetická a mimoestetická funkcia scénického umenia vychádzajúca z rituálnej podstaty divadla a mytologických zdrojov drámy na počiatku 20. storočia
}

\author{
PETRA KOVALČÍKOVÁ
}

Fakulta dramatických umení Akadémie umení v Banskej Bystrici

\begin{abstract}
Abstrakt: Štúdia sa zameriava na prenikanie rituálnych prvkov do súčasného scénického umenia. Reflexia rozoberanej problematiky sa sústredí na obdobie moderny a postmoderny v západnom kultúrnom kontexte, pričom dokumentácia javov vychádza predovšetkým z divadelných experimentov tvorcov prvej a druhej divadelnej reformy.
\end{abstract}

Klúčové slová: rytmus, rituál, mýtus, divadlo, postmoderna

\section{Situácia v scénickom umení na prelome 19. a 20. storočia}

Bohatá história divadelného umenia západnej kultúry, ktorého reflexia sa začína v období antiky, ked' formuluje svoje základné princípy a piliere prostredníctvom Aristotelovej koncepcie obsiahnutej v Poetike, zažíva z retrospektívneho pohl'adu na dejiny divadla najevidentnejší otras na prelome 19. a 20. storočia. Hoci k čiastočným krízam dochádzalo takmer v priebehu celého obdobia vývoja divadla, väčšinou sa kríza objavovala v súvislosti s predchádzajúcim stavom, ktorý sa snaží reformovat alebo reštituovat'. V priebehu 20. storočia sa však oproti ostatným historickým epochám spochybňovalo nielen predchádzajúce obdobie, ale aj samotný vývin a dejiny. Výsledkom postmoderny, nového myšlienkového smeru z konca 20. storočia najčastejšie charakterizovaného ako stav radikálnej plurality, v ktorom je dnes všetko možné a už zajtra spochybnitel'né, bola nedôvera v racionalizmus a odmietanie pokroku. Dôsledkom tohto javu - stavu radikálnej plurality - sa stal rozpad celku. Podla nemeckého filozofa a estetika Wolfganga Welscha, na rozdiel od skoršej plurality, ktorá sa objavuje napríklad v moderne, je podstatou novej plurality to, že nepredstavuje len fenomén vo vnútri celkového horizontu, ale sa dotýka každého takého horizontu. Ide k substancii, pretože ide ku koreňom. ${ }^{1}$ Ďalší z predstavitel'ov filozofického postmodernizmu, Jean-François Lyotard, v tejto súvislosti dopíňa, že moderné poznanie malo vždy formu jednoty, pričom táto jednota vznikala odkazom k vel'kým meta-príbehom. Moderna má tri takéto meta-príbehy: emancipáciu l'udstva (v osvietenstve), teleológiu ducha (v idealizme) a hermetiku (v historizme). Charakteristickou črtou nasledujúceho obdobia je, že uvedená jednota sa rozpadá: „Túžba po stratenom rozprávaní je pre vel'kú čast’ l’udstva stratená. ${ }^{\text {2 }}$

Tento rozpad celku sa postupne odrazil v socio-kultúrnom živote v podobe nástupu postmoderny, ale rovnako aj v dráme, a to vo formulovaní charakteristických znakov postdramatického divadla. Časopriestorová jednota je zrušená, uzavretú for-

\footnotetext{
${ }^{1}$ WELSCH, W. Naše postmoderní moderna. Praha : Zvon, 1994, s. 41. Preklady z českého jazyka P. K.

${ }^{2}$ Tamže.
} 
mu nahrádza otvorená. Príbeh, ktorý sa predtým odvíjal kauzálne a za sebou, aktuálne rozvíja rôzne epizódy v časovej diskontinuite vedl’a seba, teda synchrónne. Paralelne začínajú koexistovat’ rôzne žánre, formy, štýly. Prostriedkom na pretažovanie vnemu diváka či čitatela sa stáva eklekticizmus, montáž alebo demontáž príbehov. Absentuje princíp kauzality v dramatickom deji, prevláda kombinatorika štýlotvorných postupov a fragmentácia. Rozpad celku sa odrazil nielen v rozklade základnej formy drámy, ale je evidentný aj vo vnímaní subjektu. Kým v klasických drámach je subjekt zobrazený ako psychofyzická jednota, ktorú recipient spoznáva prostredníctvom spoločne prežívaných situácií, v súčasných textoch subjekt častokrát hl'adá spôsob, akým by charakterizoval a označil sám seba, pretože do kontaktu s d’alšími postavami prichádza ovela menej.

Ak hovoríme o kríze identity, ktorú divadlo a všeobecnejšie scénické umenie zažívajú v období medzi modernou a postmodernou, nejde len o krízu týkajúcu sa inscenačných postupov v scénickom diele, ktoré prestali na percipienta pôsobit'. Zároveň ide aj o spochybnenie pôvodu divadelného umenia, ktoré sa v procese vývoja scénického umenia v kontexte západnej kultúry ocitlo pod nadvládou drámy. Reakciou na túto situáciu sa stali práve experimenty prvej a druhej divadelnej reformy, v ktorých sa čoraz častejšie objavuje deštrukcia formy drámy, najmä jednej z jej základných zložiek - dejovej línie. Príbeh ako nosný pilier drámy a v ňom použitá forma kauzálneho princípu prestávajú spĺn̆at svoju estetickú úlohu, tým pádom sa začínajú rozpadat väzby medzi scénickým dielom a jeho percepciou.

Aby sme pochopili, čo sa odohráva v mysli moderného človeka, je potrebné si uvedomit, čo sa stalo s mýtmi a rituálmi, ktoré suplovali jednotu poznania, a ako sú vnímané z pohlladu súčasnej spoločnosti. Sigmund Freud v publikácii Totem a tabu rozlišuje tri myšlienkové systémy, ktoré l’udstvo vytvorilo v priebehu vekov: animistický (mytologický), náboženský a vedecký. ${ }^{3}$ Na základe identifikácie zmien v myslení a princípoch jednotlivých myšlienkových systémov, prostredníctvom ktorých sa vytvára špecifické nazeranie na ontológiu a gnozeológiu existencie človeka, je možné reflektovat’ kultúrny vývoj našej civilizácie. Krátky exkurz do načrtnutej problematiky nám pomôže objasnit, prečo dochádza ku kríze v scénickom umení v západnom kultúrnom kontexte v období moderny a postmoderny. V tejto súvislosti je dôležité aspoň stručne definovat' vztah mýtu, filozofie, vedy, umenia a ostatných odborov, ktoré sa $\mathrm{z}$ tohto vzt’ahu formovali.

Prvým medzníkom v zmene l'udského myslenia sa stáva prechod od mýtu k logu - teda k vzniku filozofického myslenia. Mytologický myšlienkový systém sa podla Freuda nesnaží vysvetl'ovat' len jednotlivé javy, ale umožňuje pochopit’ celý svet ako komplex. ${ }^{4}$ Mytologické myslenie zároveň odráža projekcie l’udskej emocionality do prírody. Podla Carla Gustava Junga sú mýty pôvodné zjavenia predvedomej duše - mimovol'né výpovede o nevedomých duševných udalostiach. ${ }^{5}$ Zjednodušene povedané, filozofické myslenie predstavuje prechod od predstáv k pojmom. ${ }^{6}$ Druhým medzníkom je novovek, ktorý sa stáva pomyselnou bránou do nového videnia sveta. Novovek totiž otvára hranice l’udského vnímania existencie života na Zemi: rozši-

\footnotetext{
${ }^{3}$ FREUD, S. Totem a tabu. Bratislava : Európa, 2015, s. 80.

${ }^{4}$ Tamže.

${ }^{5}$ JUNG, C. G. Věda o mytologii. Brno : Nakladatelství Tomáše Janečka, 1995, s. 78.

${ }^{6}$ FÜRSTOVÁ, M. Filozofia. Bratislava : MEDIA TRADE, spol. s.r.o., 1998, s. 11.
} 
ruje sa vedomie človeka o sebe samom, spoločnosti, náboženstve atd'. L'udská mysel' sa posúva za hranice konvencií, rozširuje svoje vedomosti, viac si uvedomuje seba samú. Do popredia sa dostávajú racionálne úsudky, logika a empíria, až v konečnom dôsledku dochádza k javu, ktorý by sme mohli opísat’ ako premenu z mýtického a mystického myslenia a videnia sveta na myslenie vedecké.

Pokrok vo vnímaní, ktorý sa začal v novoveku, prebral vedenie v osvietenstve, vrcholí v moderne a dodnes napreduje vo vedeckých výskumoch, však začal popri sebe samom produkovat’ aj iný jav. Približne od obdobia moderny sa objavujú koncepty, ktoré poukazujú na opačnú stranu daru, ktorý sme začali rozvíjat' - odmietanie racionalizácie. Edgar Morin, francúzsky filozof a sociológ, ktorý založil Asociáciu pre komplexné myslenie, v publikácii Veda a svedomie porovnáva racionalizmus a racionalizáciu, pričom dospieva k zaujímavému poznatku. Kým proti racionalizmu - používaniu rozumu za účelom poznania skutočnosti - nevyjadruje negatívny postoj, s racionalizáciou ostro polemizuje. Podl'a neho totiž racionalizácia znamená zmrzačenie rozumu a jeho obmedzenie na niektoré zjednodušené postupy. Tie sú často späté s formálnou logikou, takže neumožňujú uznat existenciu rozporov ani poňat' komplexnost’ skutočnosti (ktorú dokázala sprostredkovat' napríklad mytológia), pretože tá je podmienená diverzitou, s čím racionalizácia nekalkuluje. Problémom dnešnej doby sa preto podl'a Morina nestáva ani tak racionalizmus, vd’aka ktorému veda kráča vpred mílovými krokmi, ale racionalizácia sveta v jeho útržkoch, ktorá nepripúšta odchýlky a inakost.?

Neustále pokroky vo vede a technike a lipnutie na racionalizácii, ako ich vníma Morin, si vyžiadalo daň v podobe narušenia videnia existencie človeka v jeho komplementarite. Delenie problémov na časti a ich následné vyhodnocovanie $\mathrm{v}$ rámci samostatných celkov prispieva k roztrieštenému vnímaniu sveta v útržkoch. Mýtus, ktorý kedysi suploval jednotu poznania, sa teraz ocitá v kríze. A to nielen z dôvodu narušenia celostnosti poznania, ale aj preto, že dochádza k vyprázdňovaniu významov mýtických príbehov, obrazov, symbolov, metafor a pod., prostredníctvom ktorých bolo umožnené mysliet formou zástupných obrazov v širších súvislostiach. Ako tvrdí americký existenciálny psychológ Rollo May: „Bohovia starovekého Grécka a Ríma zahynuli na rovnakú chorobu ako naše krestanské symboly: l'udia zistili, že si o nich už nič nemyslia."8 Mýty a rituály sa pre pokolenie „človeka pokroku“ stali niečím, čo sa nedá overit’ v praxi. Jednotlivé príbehy, ktoré dnes v mýtoch čítame my, zobrazovali skôr všeobecné skúsenosti o tom, odkial' sme sa tu vzali, čo je našou úlohou a ako máme správne žit’. Môžeme povedat', že mýtus v sebe zahŕňal filozofiu, teológiu, antropológiu, vedu, etiku, morálku, psychológiu a vlastne všetky vedné odbory, ktoré sa časom začali separovat' a vyvíjat samostatne: „Mýtus je forma vyjadrenia, ktorá ukazuje proces myslenia a cítenia človeka - jeho uvedomenie vesmíru, druhých l’udí a seba samého, ako aj jeho reakciu na toto všetko. Ide o konkrétnu a dramatickú formu projekcie strachov a túžob, ktoré nemožno nijako ináč odhalit’ alebo vysvetlit." 9

Mýtické myslenie v sebe úmerne zahŕňalo nielen racionálne, ale aj emocionálne či zmyslové poznanie sveta. Toto poznanie bolo následne „kódované“ do dramatickej

\footnotetext{
${ }^{7}$ MORIN, E. Věda a svědomí. Brno : Atlantis, 1995.

${ }^{8}$ MAY, R. Túžba po mýtoch. Bratislava : IKAR, 2007, s. 25.

${ }^{9}$ Tamže, s. 22.
} 
formy, ktorej dominoval príbeh. Ten vytváral jednotu, no práve ona sa v procese vývoja dejín a kultúry rozpadá. Vedecký prístup totiž posúva poznanie človeka vpred najmä prostredníctvom racionálnych argumentácií a verifikácií téz. Táto racionalizácia sveta v útržkoch postupne potlačila do úzadia poznávanie na základe subjektívneho prežívania emocionálnej skúsenosti, a preto sa potreba komplexnosti poznania formuluje $\mathrm{v}$ priebehu 20. storočia ako niečo, čo začína $\mathrm{v}$ našej spoločnosti chýbat'. Tento jav vyústil do mytologickej krízy, ktorej aktuálne čelí moderná západná konzumná spoločnost'. Umenie ako jedna z mála oblastí, ktoré sa formovali z rituálnych a mytologických základov, si zachovalo schopnost' zachytit' komplexnost' poznania a snaží sa ju oživovat’ práve začiatkom 20. storočia.

Pre situáciu v scénickom umení v západnom kultúrnom kontexte na konci 19. storočia bolo príznačné, že scénické zložky sa dostali pod nadvládu písanej drámy a všetky vtedajšie inscenačné postupy a metódy sa podriad’ovali výlučne interpretácii textu. Podl'a nemeckého komparatistu a divadelného vedca Hansa-Thiesa Lehmanna sa západné divadlo nachádzalo na konci dlhého obdobia rozkvetu ako vypracovaná diskurzívna formácia, ktorá napriek všetkým rozdielom umožňovala prijímat Shakespeara, Racina, Schillera, Lenza, Büchnera, Hebbela, Ibsena a Strindberga ako rôzne druhy rovnakej formy diskurzu, v ktorom sa aj nanajvýš divergentné typy a mimoriadne osobnosti javili ako variácie jednej diskurzívnej formácie, pre ktorú je podstatné zlievanie drámy a divadla. ${ }^{10}$ Diskurzívna forma divadla, v ktorej začala prevládał’ naratívnost' a ilustratívnost' textovej predlohy, spôsobila „oddivadelnenie divadla“, čo sa prejavilo v oslabenom pôsobení výsledného scénického tvaru a jeho dramatického účinku: „Približne od roku 1880 dochádza ku kríze drámy, ktorej predzvestou boli zatial' nerevolučné zmeny divadla. To, čo sa v dráme spochybňuje a čo sa z nej vytráca, je séria dovtedy samozrejmých konštituentov: textová forma dialógu plného napätia a rozhodnutí; subjekt, ktorého skutočnost' sa v zásade dá vyjadrit' l'udskou rečou; dej, ktorý sa prednostne odvíja v absolútnej prítomnosti. “" $\mathrm{Z}$ vývinovej (historickej) perspektívy môžeme konštatovat', že scénické umenie postupne strácalo pôvodný silný rituálny charakter bezprostrednej udalosti a začalo sa od publika oddel'ovat', uzatvárat’ do budov a strácat’ kontakt s divákom za pomyselnou štvrtou stenou.

Táto situácia si žiadala zrušenie všetkých predchádzajúcich princípov. Aj z tohto dôvodu, ako d’alej tvrdí Lehmann, sa paralelne a analogicky ku kríze drámy ako textovej formy vztahujúcej sa na divadlo začína prejavovat skepsa voči kompatibilite drámy a divadla. ${ }^{12}$ Tá sa objavuje už vo vrcholnom období moderny: „Napríklad Pirandello bol presvedčený o nezlučitel’nosti divadla a drámy. Edward Gordon Craig v Prvom dialógu knihy Umenie divadla píše, že Shakespearove vel'ké hry by sa vôbec nemali hrat' na javisku! Je to vraj dokonca nebezpečné, lebo hraný Hamlet zabíja čosi z nekonečného bohatstva imaginárneho Hamleta. (Craig neskôr túto hru inscenoval a vyhlásil, že tento pokus potvrdil jeho tézu o nemožnosti uviest’ Hamleta.) Divadlo sa tu chápe ako niečo, čo má vlastné, inak uspôsobené a vo vzt’ahu k dramatickej literatúre dokonca nepriatel'ské korene a predpoklady. Craigov záver znie, že text treba divadlu zobrat’ - práve pre jeho poetické dimenzie a kvality. ${ }^{\prime 13}$

\footnotetext{
${ }^{10}$ LEHMANN, H.-T. Postdramatické divadlo. Bratislava : Divadelný ústav, 2007, s. 55.

${ }^{11}$ Tamže, s. 56.

12 Tamže.

${ }^{13}$ Tamže.
} 


\section{Potreba obnovy interakčných rámcov medzi javiskom a hl’adiskom}

Divadelné umenie na prelome 19. a 20. storočia značne ovplyvnili antropologické štúdie, ktoré mu poskytli východisko najmä teóriami o jeho vzniku a pôvode. Výrazný vplyv mala Cambridgeská ritualistická škola, predovšetkým publikácie filozofky Jane Ellen Harrisovej (1850 - 1928). Podla jej tézy artikulovanej vo filozofickej práci Prolegomena k štúdiu gréckeho náboženstva (1903) ${ }^{14}$ stál na počiatku náboženských predstáv apotropaický rituál. Súčasný český antropológ Ivo T. Budil ho vysvetluje ako magický úkon zameraný na ochranu úrody a obydlia. Personifikáciou rituálnych úkonov sa následne zrodil daimon - grécky bôžik vegetácie a plodnosti, ktorý bol predchodcom „,vel'kých" bohov. ${ }^{15}$

Popri Harrisovej sa touto témou zaoberali aj Gilbert Murray (1866 - 1957) a Francis Macdonald Cornford (1874 -1943). Pre divadelné umenie mala najväčší význam pravdepodobne Murrayova práca Excursus on the Ritual Forms preserved in Greek Tragedy (1912), kde dokazoval, že starogrécka tragédia sa vyvinula z tanečných rituálov dionýzovského kultu, pričom scenár náboženských obradov, z ktorých sa zrodila tragédia, mal podla neho nasledujúcu štruktúru: 1. agon - súboj medzi božstvom a jeho úhlavným nepriatel'om; 2. pathos - boh spätý s ročným cyklom umiera obetnou smrtou; 3. posol/messenger - zvestovanie smrti boha; 4 . therenos - oplakávanie, lamentácia; 5. anagnorisis - usmrtený boh je rozpoznaný; 6. teofania - boh manifestačne vstáva z mŕtvych. ${ }^{16}$

Bol to práve Murray, kto vyslovil predpoklad, že tragédia sa vyvinula z prvotného rituálu - sacer ludus. ${ }^{17}$ Aj ked' o vývine dramatických žánrov z prvotného rituálu neexistujú žiadne priame dokumenty, Cambridgeská škola prispela k tomu, že divadlo začína hl'adat' svoj pôvod v mýtoch a rituáloch. Scénické umenie západnej kultúry prechádza v tomto období krízou, v rámci ktorej po prvýkrát uvažuje o svojom pôvode, zdroji a snaží sa samo seba definovat’ a vymedzit sa voči dráme. Výsledky výskumu teórií o vzniku divadla viedli k autonomizácii divadla od drámy. Ako píše Lehmann: „V rámci všeobecnej umeleckej revolúcie na prelome 19. a 20. storočia dochádza paralelne ku kríze drámy aj ku kríze formy diskurzu samotného divadla. $Z$ odmietania tradovaných divadelných foriem sa vyvinula novodobá autonómia divadla ako samostatnej umeleckej praxe. Až od tohto zvratu sa divadlo pri vol'be svojich prostriedkov vzdalo bezpečnej orientácie na požiadavky drámy určenej na inscenovanie. Táto orientácia neznamenala pre divadlo iba obmedzenie, ale poskytla mu zároveň určitú istotu remeselných kritérií, logiku a zákonitost' využitia divadelných prostriedkov slúžiacich dráme. S novonadobudnutou slobodou sa v tomto smere spájala aj strata, ktorú z produktívneho hl'adiska môžeme opísat ako vstup divadla do éry experimentovania." ${ }^{18}$

V tomto prelomovom období začína divadlo hladat’ svoj pôvod v mytológii a rituáloch. Pri realizácii experimentov zameraných na obnovu spojenia medzi divákom a hercom sa obracia $\mathrm{k}$ východnému a ázijskému umeniu, prekračujúc tak hranice

\footnotetext{
${ }^{14}$ BUDIL, I. T. Mýtus, jazyk a kulturní antropologie. Praha : Triton, 2003, s. 252.

${ }^{15}$ Tamže.

${ }^{16}$ Tamže, s. 253.

${ }^{17}$ SCHECHNER, R. Performance Theory. London : Routledge, 2003, s. 4.

${ }^{18}$ LEHMANN, H.-T. Postdramatické divadlo, 2007, s. 57.
} 
umenia smerom k antropológii. Prenikanie prvkov rituálov a obradov úzko súvisí s druhou divadelnou reformou, ktorú v rovnomennej publikácii z roku 1979 popisuje pol'ský teatrológ Kazimierz Braun. Môžeme ju chápat’ vo viacerých súvislostiach, avšak súvisí najmä so zmenou inscenačných postupov a usporiadania divadelného priestoru. Podobne ako pre postmodernistické koncepcie, aj pre druhú divadelnú reformu je príznačným rozpad celku, konkrétne rozbitie štruktúry scénického diela. Nejde teda o uzavretý, statický útvar, odrážajúci na scéne istú skutočnost́, ani o samotný obraz či o obrysy uzavretého útvaru, ktoré už predtým vznikli v predstavách jeho tvorcu - inscenátora. ${ }^{19}$ Naopak, ide napr. o aspekty, ktoré Braun charakterizuje ako prejavy inscenačných konceptov druhej divadelnej reformy: „Spoluúčast', participácia. Improvizácia. Work in progres. Free theatre. Happening. Inscenácie, ktoré majú iba skúšky. Improvizované premiéry bez skúšok. Verejné skúšky bez premiéry. Kolektívna tvorba. Rôzne verzie rovnakých inscenácií. Vol’né inscenačné štruktúry závislé na rozložení divákov a hercov, na priestorových a klimatických podmienkach, na politických pomeroch a na stupni ostražitosti cenzúry. Začiatky predstavenia v hladisku ešte predtým, ako sa začalo predstavenie na scéne. Prenášanie akcie zo scény do hl'adiska. Z hl'adiska na scénu. Prerastanie drámy do akejsi diskusie, diskusia do ukážky, ukážka v manifestáciu, z manifestácie do happeningu, mierového pochodu, do demonštrácie v masové agitačné divadlo. Zdivadelnenie života. Život divadlom. ${ }^{\text {20 }}$

Hlavnú čast’ druhej divadelnej reformy sformulovali $\mathrm{v}$ teoretických úvahách a praktických prácach významní divadelníci, napr. Antonin Artaud, John Cage, Bertolt Brecht, Tadeusz Kantor a Richard Schechner. Artaud vo svojom manifeste divadla krutosti znova definuje podstatu divadelného diela a jeho stvárnenia, pričom sa vyjadruje ku všetkým divadelným zložkám - k dramaturgii, réžii, postaveniu autora hry, scénografii, svetlám, času, hudobnej zložke, funkcii diváka a v neposlednom rade $\mathrm{k}$ hereckému prejavu a spôsobu, akým má divadelné dielo komunikovat’ s divákom. Brecht doplnil Artaudove myšlienky najmä v súvislosti s hereckou zložkou diela a s funkciou, akou by malo dielo k divákovi prehovárat'. Odporučil kritický vztłah k svetu a kritické herectvo (kritické nielen voči predvádzaným udalostiam, ale aj voči stvárňovanej postave), inštrumentálne „mimoumelecké“ využívanie divadla ako prostriedku pre ideologické, spoločenské a politické pôsobenie. Predstavenie už nemalo skutočnost’ vytvárat', ale ju ukazovat'. Cage sústredil pozornost' na problematiku spoluúčasti, ktorú reflektujeme ako základný prejav vplývania rituálu na scénické umenie, ked' skúmal možnosti zámeny úloh medzi divákmi a hercami. Analogicky k tejto situácii odporúčal, aby sa stierala hranica medzi životom a umením. V oblasti divadla bol predchodcom tzv. „work in progress “ a "osobnostného herectva“. Kantor zase nastolil problém samej existencie divadla: v najhlbších vrstvách svojej tvorby sa javí byt predchodcom tých, ktorí bolestne vidia a prežívajú premeny divadla ohlasujúce jeho zánik v doposial' neznámych formách, a tých, ktorí opätovne vytvárajú divadlo založené na protiklade umenia a života. Tieto zámery rozvíjali a interpretovali aj d’alšie divadelné osobnosti, spoločnosti a zoskupenia, napr. Living Theatre, Jerzy Grotowski, Peter Brook, Eugenio Barba, Robert Wilson a mnohí iní. Druhá divadelná reforma a jej experimentovanie s jednotlivými zložkami scénického umenia ovplyv-

\footnotetext{
${ }^{19}$ BRAUN, K. Druhá divadelní reforma. Praha : Divadelní ústav, 1993, s. 30.

${ }^{20}$ Tamže, s. 35.
} 
nili vznik nových foriem divadelnej inscenačnej praxe (site specific, happening, devised theatre a pod.).

Na teoretické východiská Cambridgeskej ritualistickej školy a divadelné experimenty druhej divadelnej reformy plynulo nadviazali performatívne štúdiá, ktoré sa začiatkom osemdesiatych rokov 20. storočia sformovali ako samostatná akademická disciplína. Priekopníkom v tejto oblasti bol Richard Schechner, a to najmä vd’aka práci Performancia: teórie, praktiky, rituály (1988). Neskôr na ním ponúknuté východiská nadviazali a problematiku performatívnych štúdií rozvinuli d’alší teoretici, napr. Aleksandra Jovićević, John Langshaw Austin a iní. Schechner vo svojich teóriách pracuje s pojmom performancia, pod ktorý sústred’uje viacero činností l’udských aktivít vykazujúcich podobnú štruktúru v čase ich uskutočňovania. Do performačných činností zahŕňa aj scénické umenie. Performanciou za istých okolností môže byt’ podl'a neho šport, hry, rituály, spoločenské drámy a iné, avšak medzi hlavné kategórie performačných činnosti radí estetické divadlo, náboženský rituál, svetský rituál, šport a spoločenskú drámu. ${ }^{21}$ Performancia v zmysle, ako ju vníma Schechner, má funkciu spoločne zdiel'anej udalosti, v ktorej sa skupina l’udí rozhodne vystúpitł z časopriestorového kontinua bežného života, prijat’ nové úlohy súvisiace s vytváraním udalosti a uskutočňovat' ich a/alebo byt' účastníkom novovytvoreného časopriestoru a jeho obsahu. Po realizácii konkrétneho obsahu sa tento "fiktívny“ časopriestor opustí a účastník sa vráti spät do bežného života. V konkrétnych performačných činnostiach (šport, spoločenská dráma, rituál, ale najmä scénické umenie) vidí základnú podmienku k ich vzniku, ktorou je konflikt. Ten je podl’a Schechnera prípustný len v štruktúre performovania, nie v celkovej štruktúre performancie. ${ }^{22}$

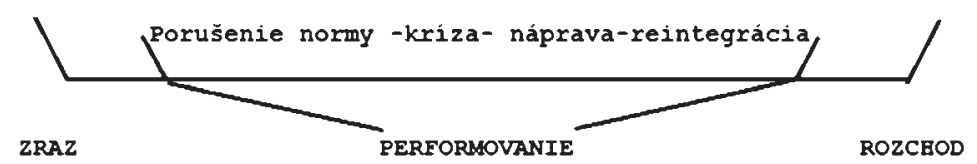

V spôsobe, akým Schechner popisuje fázy alebo štruktúru performancie, jednoznačne badáme analógiu s dramatickou štruktúrou drámy, ako ju definoval Aristoteles. Koncept Aristotelovho oblúka vývinu udalostí v dráme môžeme nájst' výhradne v časti, ktorú Schechner označil ako performovanie. Jednotlivé časti - úvod, kolízia, kríza, peripetia, katastrofa - sú v zovšeobecnenej forme obsiahnuté v časti štruktúry, s ktorou Schechner pracuje a ktorá je predmetom obsahu performančných činností. Tento pohlad rozširuje nazeranie na divadlo ako na spoločenskú udalost', v rámci a vnútri ktorej sa odohrá dráma - t.j. performovanie. Divadelná udalost’ pracuje so svojím obsahom, t.j. drámou (v inscenovanej podobe) ešte predtým, než je predvádzaná pred publikom, a to nielen prostredníctvom inscenačného procesu, ktorý prebieha určitý čas pred uvedením diela, ale najmä rozdelením úloh na percipientov a realizátorov a prijatím týchto úloh tesne predtým, ako bude scénické dielo vzhliadnuté. Ondrej Kaščák vo svojom výskume v oblasti komparatívnej pedagogiky tvrdí: „Rituál je pre jeho účastníkov komplex záväzných aktivít, ktorý svoju legitimitu čerpá z tradície, a preto nepotrebuje racionalizáciu svojej oprávnenosti. Účast-

\footnotetext{
${ }^{21}$ SCHECHNER, R. Performancie, teórie, praktiky. Bratislava : Divadelný ústav, 2009, s. 192.

${ }^{22}$ Tamže, s. 193.
} 
ník rituálu sa tak nachádza v situácii, ked’ sú stanovené relatívne pevné interakčné rámce, ked’ je stanovená jasná vzţahová štruktúra, a ked’ sú predvolené obsahy interakcií. " ${ }^{23}$ Skutočnost', že ide o zautomatizovaný akt prebratia konkrétnych úloh spoločenstva v momente predvádzania deja, poukazuje vo vyššie zmieňovaných súvislostiach na zautomatizovanú/,zabudnutú" estetickú, ale aj mimoestetickú funkciu divadla vychádzajúcu z jeho rituálnej podstaty, ktorá sa vývojom západného divadla zatlačila do úzadia. Ide o funkcie a pôsobenie scénického umenia principiálne identické s funkciou rituálov v konkrétnom spoločenstve l'udí: „V tomto sociálne preddefinovanom rituálnom rámci je účastník rituálu vedený od činnosti k činnosti s cielom dosiahnut’ určitú zmenu v jeho správaní, pohlade na svet či zmenu v jeho sociálnej pozícii. Zmyslom rituálov je teda riadená osobnostná transformácia. “24

Rituály vo všeobecnosti súvisia s potrebou realizácie osobnej alebo spoločenskej zmeny, pričom primárnou funkciou rituálnych a ritualizovaných činností je snaha „zahubit" predošlý stav v prospech stavu nového. Rituál slúži nielen ako nástroj k fixácii a automatizácii zmeny, ktorú je potrebné v spoločnosti vykonat', ale tiež ako nástroj k realizácii zmeny, teda k rozbitiu predchádzajúcej automatizácie v prospech novej zmeny: „Rituál nie je racionálna reakcia, ale je to najúčinnejší súbor techník pre manipuláciu identít v rámci dobra kmeňovej lojality. Apeluje na hlboké emócie, na priamu a vnútornú skúsenost' kolektívnej jednoty za cenu potlačenia individuality jedinca a racionálnejšieho seba. “25 Ako zdôrazňuje Kaščák, pri rituáloch je dôležitá edukačná funkcia založená na emocionálnom prežití a kolektívnej účasti konkrétnej udalosti: „Vedenie sprostredkované v rituáloch má svoje tzv. telesné formy - vztahujúce sa na telesné spôsobilosti, na ritualizácie, na mimesis a rytmus ulice. Takéto telesné vedenie je odlišné od poznania - čiže analytického odhal'ovania faktov a empirických informácií. Základné formy učenia sa prostredníctvom rituálu totiž prebiehajú nemo, bez slov a pojmov, mimetickým spôsobom, od tela k telu. Znamená to, že dôležitá komunikatívna funkcia rituálov spočíva $v$ tom, sprostredkovat’ vedenie in actu, t. j. vedenie v konaní. (...) Rituály nehovoria o rolách, o pravidlách, o vztahoch a pohl'adoch na svet, ale v rolách, vo vztahoch, v pravidlách a pohl'adoch na svet (...).“26

Scénické umenie sčasti túto edukatívnu funkciu preberá a pracuje s ňou vlastnými prostriedkami. Divadelné experimenty tvorcov prvej a druhej divadelnej reformy prispeli $\mathrm{k}$ tomu, že je potrebné opätovne nájst’ estetické a mimoestetické pôsobenie scénického diela na diváka. Zároveň tieto experimenty poukazujú na to, že aby niečo také vôbec bolo možné, je tiež potrebná či až nevyhnutná redefinícia funkcie percipienta z diváka - nezainteresovaného pozorovatel’a, na diváka - účastníka.

\section{Redefinícia estetickej funkcie scénického umenia}

Inscenačná prax divadelného umenia 20. storočia poukazuje na opotrebovanie interakčných väzieb drámy a jej percepcie. Práve v experimentálnej tvorbe inscenáto-

${ }^{23}$ KAŠČÁK, O. Význam a miesto rituálov v pedagogickej teórii a praxi. In Pedagogická orientace, 2009, roč. 19, č. 2 , s. 38 .

${ }^{24}$ Tamže.

${ }^{25}$ KOSTER, J. Ritual performance and the politics of identity. [online]. [cit. 10. 2. 2019]. Dostupné na internete: http://wwww.let.rug.nl/koster/papers/JHP.Koster2.Edit.pdf.

${ }^{26}$ KAŠČÁK, O. Význam a miesto rituálov v pedagogickej teórii a praxi, s. 46. 
rov prvej a druhej divadelnej reformy reflektujeme snahu hl'adat’ a tvorit’ nové formy estetického pôsobenia drámy na diváka. K tomu, aby sa obnovil vzt’ah medzi adresátom a adresantom, inscenátori vytvárajú rozmanité techniky a metódy, s ktorými $\mathrm{v}$ rôznych pomeroch viac či menej úspešne pracujú.

Bez estetického účinku nie je možné odkaz diela odovzdat’ percipientovi. Preto môžeme konštatovat', že v scénickom umení je estetická funkcia nadradenou a primárnou, ked’že dokáže vytvorit’ spojenie medzi divákom a scénickým dielom, aby potom mimoestetickým pôsobením, napr. sprostredkovaním vedenia prostredníctvom zážitku do vedomia, vtlačila odkaz alebo ideu diela do vnímania pozorovatela. V kontexte vývinu západnej divadelnej kultúry slúžili k vytvoreniu vzt’ahu medzi javiskom a hl'adiskom predovšetkým empatia a katarzia. Tradičné európske divadlo vychádza z konceptu aristotelovského modelu drámy, pričom dôraz je kladený na dej, kauzalitu a naráciu. Spôsob divákovej participácie a estetická funkcia, ktorú tradícia západného divadla rozvíja, sa zameriava na rozpoznanie dejovej línie alebo štruktúry deja, charakterov a vztahov postáv. Prostriedkom participácie sa v tomto prípade stáva empatia - schopnost’ vcítenia sa do postáv a motivácíi ich konania. Účinkom tohto konceptu je katarzia - prežívanie deja dramatického diela. Ku katarzii za optimálnych podmienok dochádza pred katastrofou, čiže úplným záverom diela. Aby sa docielila schopnost' vcítit sa do postáv a spolu s nimi prežívat' fiktívny, na scéne sa odohrávajúci dej alebo situácie, je potrebné čerpat’ z podobností charakterov a dejov zo života, čo Aristoteles označil pojmom mimézis.

Z uvedeného hladiska je vnútorným prvkom takého typu drámy istá forma gradácie situácií na podklade dramatického oblúku (úvod - kolízia - kríza - peripetia - katastrofa), ktorá je vytváraná kauzalitou situácií alebo v neskoršom období ich montážou (moderná a najmä postmoderná dráma). Princíp dramatickosti spočíva a vychádza zo schopnosti vcítił’ sa. Predstavitel' divadelnej estetiky Otakar Zich v tejto súvislosti tvrdí: "Ak pozorujeme konanie l’udí, či už v živote alebo na scéne, vybavujeme si svoje vlastné skúsenosti motorického charakteru úplne bezprostredne a bez toho, aby sme túto okolnost' uvedomovali; vybavujú sa nám tým hojnejšie a tým silnejšie, čím dokonalejšie sa do konania druhých vžívame, čo samozrejme činíme práve pri vnímaní divadelnom. A nevybavujú sa nám len motorické predstavy; okrem toho sme strnutí $\mathrm{k}$ vlastnému napodobneniu toho, čo vidíme a počujeme, a to aspoň v akýchsi náznakoch, ktoré postačujú na to, aby sme sa do konania iných úplne vžili. (...) Duševným odrazom tejto aktivity sú dva city (vlastne skupina citov), totiž cit dramatického napätia, resp. uvol’nenia a vzrušenia, resp. upokojenia.“27

Aby bol divák schopný empaticky sa naladit’ na predvádzaný dej, je dôležité zapojit' d’alšiu jeho schopnost' - pozorovanie. Bez sústredeného pozorovania diania na scéne je priamoúmerne znižovaná schopnost' vcítit’ sa do charakteru alebo deja, a tým pádom prežitia finálneho, katarzného účinku deja diela. Experimenty prvej a druhej divadelnej reformy však priniesli snahy vytvoritł spojenie medzi divákom a hercom, ktoré by fungovalo na inej báze, pričom inšpiráciu nachádzali práve v rituálnom pôvode divadla. Vzhl'adom na to, že dej modernej a postmodernej drámy je postupne fragmentovaný na kratšie výstupy (scény), neraz časopriestorovo nekompatibilné, empatia ako nástroj vytvorenia potrebného spojenia medzi divákom a hercom pre-

${ }^{27}$ ZICH, O. Estetika dramatického umění. Praha: Panorama, 1986, s. 39. 
stáva byt účinná. Aj z tohto dôvodu hl’adajú tvorcovia nové zdroje, v ktorých by objavili spôsob, akým by bol obnovený alebo nahradený katarzný účinok drámy. Tie vychádzajú z rituálnej a mytologickej podstaty divadla, a preto inscenátori nachádzajú inšpiráciu práve $\mathrm{v}$ antropologických výskumoch $\mathrm{tzv}$. prírodných národov, v čínskom a japonskom umení a v indonézskej kultúre.

Aj tradičné európske divadlo nepochybne vychádza z rituálnych prvopočiatkov, avšak rozvíja predovšetkým oblast’ pôsobenia scénického diela, ktorá sa sústred'uje na vnímanie. Naproti tomu, tradícia východného divadla a umenia vo väčšej miere pôsobí na divákovu intuíciu a emocionalitu. Tá fascinuje niektorých európskych tvorcov práve z hladiska estetickej funkcie, prostredníctvom ktorej pôsobia na divákovu percepciu. Ide najmä o gestá, obrazotvornost', masky, spôsob herectva atd'. V tejto súvislosti môžeme spomenút napríklad Antonina Artauda, ktorého k úvahám o divadle inšpirovalo predstavenie súboru z Bali, či Bertolta Brechta, ktorý formuloval odcudzovací efekt epického divadla z efektu scudzenia, ktorý videl v čínskom divadle. Michail Čechov v publikácii Psychológia gest (1920) formuluje hereckú techniku vychádzajúcu z antropozofie Rudolfa Steinera, pričom Steiner čerpal inšpiráciu najmä z indických filozofických systémov. Všeobecne známy je obdiv k japonskej kinematografii, divadlu Nó a japonskej kultúre u Ariane Mnouchkinovej, ale aj mnohých d’alších tvorcov, ktorí svoju divadelnú prax založili na antropologických výskumoch (napr. Grotowski, Barba, Brook a iní).

Jeden z konceptov, s ktorým východné divadlo pracuje a na ktorom buduje svoju tradíciu, je džo-ha-kjú. Princíp progresie džo-ha-kjú sa spája s osobnostou Motokyja Zeamiho (1363 - 1443), japonského estetika, herca a dramatika, ktorý sa do povedomia európskej a americkej divadelnej spoločnosti dostal opät’ koncom 19. storočia. Aj japonský herec a režisér Yoshi Oida, známy najmä tvorbou pre divadelnú spoločnost’ Petra Brooka v Paríži, opisuje v článku nazvanom The notion of Jo Ha Kyu jednoduché cvičenie s hercami, ktoré absolvujú preto, aby im vysvetlil princíp fungovania rytmickej schémy, ktorú už kedysi dávno formuloval Zeami: „Často žiadam hercov, aby si posadali do kruhu, zavreli oči a tlieskali spolu rukami, kým sa zvuk tlieskania nezjednotí. Žiaden vedúci, žiadny predpísaný rytmus. Vždy, ked’ sa skupina zladí, tlieskanie sa začne zrýchl'ovat', až kým nedosiahne svoj vrchol. Potom sa tlieskanie opät náhle spomalí, avšak nie na úroveň predošlého tlieskania, a ešte raz sa začne zrýchl'ovat’ k druhému vyvrcholeniu. A tak d’alej. Pred šest'sto rokmi majster japonského divadla Nó, Zeami, povedal: ,Každý fenomén vo vesmíre je podmienený určitým postupom progresie. Dokonca aj spev vtákov, alebo zvuk chrobákov nasledujú tento postup. Volá sa džo-ha-kjú." "28

Oida d’alej uvádza, že v takejto schéme sa začne pomaly, potom postupne a plynulo zrýchl'ovat’ smerom k vel'mi rýchlemu vrcholu. Po vrchole sa zvyčajne nachádza pauza, potom sa opätovne spustí celý akceleračný cyklus odznova. Japonológ Ivan Rumánek dodáva, že celý princíp džo-ha-kjú je zložený z piatich stupňov označovaných „dan“: „Zeami v pojednaniach Fúšikaden a Sandó píše o troch fázach predstavenia $\mathrm{z}$ hl'adiska dynamiky: džo, ha a kjú. Džo znamená úvod, ha by sa dalo preložit’ ako ,rozbitie' a kjú ,zrýchlenie', pričom aj samo ha sa ešte delí na druhotné džo-ha-kjú. Takto sa hra skladá z piatich stupňov označovaných dan. Prvý dan - džo - je

${ }^{28}$ The Notion Of Jo, Ha, Kyu. [online]. [cit. 12.3.2019]. Dostupné na internete: https://understandingcinema.files.wordpress.com/2013/11/the-notion-of-jo-ha-kyu.pdf. 
vstup wakiho a wakicureho po koniec ich spoločnej piesne. Druhý dan - začiatok ha (,haové džo') - je výstup šiteho a jeho pieseň. Tretí dan - stred ha (,haové ha') - je stretnutie wakiho a šiteho, ich rozhovor a prvá pasáž zboru. Štvrtý dan - koniec ha (,haové kjú') - tvorí jadro hry, jej pohybovo-slovné tažisko, do ktorého sa z tohto dôvodu zarad'uje práve kusemai ako špecifická zložka hry. Piaty dan - kjú - môže byt' tanec alebo energické pohyby šiteho v rýchlom rytme. ${ }^{\text {} 29}$

\begin{tabular}{|l|lll|l|}
\hline \multirow{2}{*}{ DŽO } & HA & & KJÚ \\
\cline { 2 - 3 } & DŽO & HA & KJÚ & \\
\hline 1. Dan & 2. Dan & 3. Dan & 4. Dan & 5. Dan \\
\hline
\end{tabular}

Každá hra, čin, scéna aj individuálna reč v japonskom divadle majú vlastné Džo-há-kjú. Dokonca aj gesto, akým je zdvihnutie ramena, sa začne s určitou rýchlostou a končí mierne rýchlejším rytmom. Stupeň zrýchlenia sa môže líšit: niekedy je pre diváka celkom evidentným, inokedy je zmena tempa taká mierna, až sa zdá, že nie je viditel’ná. Avšak vždy je prítomná, zmysel d’alšieho stupňovania totiž nikdy nesmie absentovat'. Niekedy sa povrch akcie môže spomalit’ alebo úplne zastavit'. V tomto prípade nemusí byt’ džo-ha-kjú úplne zretel’né, napriek tomu sa stále vyvíja na vnútornej úrovni. Vo všeobecnosti sa rytmus džo-ha-kjú pripodobňuje k rytmu organickému, biologickému či, mohli by sme povedat', inštinktívnemu, a ten je možné l’ahko pozorovat’ a porovnat’ so sexuálnym aktom končiacim orgazmom.

Dokladom toho, že z dedičstva východných kultúr dnes čerpá viacero umelcov, je napríklad technika, ktorú sformulovali americké režisérkyAnne Bogart a Tina Landau. Predstavujú ju v publikácii, ktorá vyšla v českom preklade Úhly pohledu: Praktický průvodce systémem úhlů pohledu a kompozice a je koncipovaná ako praktický sprievodca tréningu uhlov pohl'adov so zameraním aj na metódu kolektívnej tvorby. Autorky členia svoje praktické skúsenosti do dvoch častí. Prvá je formulovaná ako uhly pohladov - herecká metóda obsahujúca aj konkrétne cvičenia na rozvíjanie hereckej kreativity. Druhá čast’ sa venuje kompozícií výsledného divadelného diela. Princíp džo-ha-kjú vnímajú ako rytmický vzorec objavujúci sa v hereckých akciách, ale aj v celkovom usporiadaní scén alebo sekvencií divadelného diela. Na podklade Zeamiho úvah nachádzajú tento rytmický vzorec v celkovej divadelnej udalosti, d’alej v predvádzanej inscenácii, vo vztahoch postáv, situáciách či v konaní hercov na scéne: „Večer má džo-ha-kjú. Hrá má džo-ha-kjú. Výstup má svoje džo-ha-kjú. Scéna má svoje džo-ha-kjú. Vztłah má svoje džo-ha-kjú. Akcia má džo-ha-kjú. Gesto má džo-ha-kjú. “30

Rytmická štruktúra obsiahnutá v produkciách východného divadla poskytla tvorcom 20. a 21. storočia stále živý zdroj rituality, ktorý ponúka východiská k tomu, aby bolo možné vytvorit” „nové“ spojenie medzi percepciou a predvádzanými udalostami na scéne. Jednou z možností sa pritom stáva využívanie rytmických foriem a rytmizovaných činností. Z lingivistického hl'adiska je „rytmus“ odvodený z gréckeho slova ho rhythmos, pričom podla Bohumila Nusku bol tento pojem formulovaný práve v oblasti gréckej antickej civilizácie. Ho rhythmos znamená prúdenie, pravidelný

\footnotetext{
${ }^{29}$ RUMÁNEK, I. Japonská dráma nó. Žáner vo vývoji. Bratislava : Veda, 2010, s. 187.

${ }^{30}$ BOGART, A. Úhly pohledu. Praha : Divadelní ústav : Divadlo Archa, 2007, s. 140.
} 
pohyb, a preto bývalo spájané s časom, ked’že vo svojej podstate "prebieha v čase“: „V koreni slova gréckeho ho rhytmos, v pôvodnom význame ,prúdenie', s ktorým sa bytostné spája i predstava temporality, je grécke sloveso rheó, rhein vo význame, že niečo plynie, tečie, prúdi. “" ${ }^{11}$ Nuska d’alej upozorňuje na súvislosti s gréckymi substantívami ako sú hé rhésis - hovorenie, hé rhétra - reč, to rhéma - prehovor, konkrétna reč, ho rhétor - rečník, he rhetoriké - rečnenie, rétorika. ${ }^{32}$ Už z tohto hl'adiska je vidiet, že antická kultúra vnímala rytmus najmä vo verbálnom prejave človeka. Chápanie rytmu v kontexte antickej kultúry a v kontexte verbálneho/zvukového/ akustického prejavu človeka potvrdzujú aj práce niektorých filozofov, ktorí venovali pozornost’ tomuto fenoménu. Najvýraznejšími z nich sú Platón, Aristoteles, a Aristoxenos.

Platónove chápanie rytmu je v prvom rade podmienené dedičnostou. $V$ jeho diele Zákony je zachytený výrok Aténčana, v ktorom sa uvádza, že už na počiatku múzického a gymnastického umenia sám boh umenia Apollón „vštepil nám l’ud’om zmysel pre rytmus a harmóniu“33. Aristotelove poznatky o rytme, ktoré považujeme za určujúce v súvislosti s vývojom divadla západnej kultúry, sú najmä tie, v ktorých rytmus označuje ako biologickú danosť človeka. Preto ten, kto rytmus vytvára, ale aj rozpoznáva, dokáže mat' z jeho napodobňovania pôžitok: „,Rytmus svojou existenciou zodpovedá l'udskej prirodzenosti, pretože našej prirodzenosti zodpovedá napodobňovanie a tiež melódia a rytmus. (...) Od prírody teda máme schopnost' napodobňovat’ rovnako, ako máme zmysel pre melódiu a rytmus; verše sú totiž druhy rytmov.." ${ }^{\text {"34 }}$ Je dôležité poznamenat', že Aristoteles vo svojich prácach spomína rytmus najmä vo vzt’ahu k dynamike reči a akustickým prejavom človeka a používa rytmus výhradne v kontexte s dýchaním. Ked’že antická dráma je písaná v prvom rade formou prozodických systémov, pričom obsahuje nielen monologické a dialogické pasáže, ale aj text určený pre chór, môžeme tvrdit', že je to práve rytmizácia akustického prejavu a textovej zložky drámy, čo dominovalo v období antiky.

Aristoxenos, považovaný za zakladatel'a hudobnej vedy, opieral teóriu rytmu o jeho auditívnu vnímatel'nost’ prostredníctvom hudby. Ako vysvetluje Bohumil Nuska: „Rytmus podla Aristoxena je považovaný za delenie či rozdelovanie času $\mathrm{v}$ stanovenom, danom poriadku a rytmus sa skladá z formujúceho princípu (rhytmizón) a formovanej látky (rhytmizómenon). (...) Rhytmizómenon, t. j. to čo je formované, môže byt’ pri tom prezentované rečou, melódiou, alebo pohybom tela, pričom rytmus de facto spája rôzne umenia, ktoré sú realizované v čase a pohybom." ${ }^{35}$ Hoci v nadväznosti na uvedené autor tvrdí, že v žiadnej inej zo starovekých kultúr sa nestretávame s adekvátnym pojmom k pojmu rytmus, uvádza i d’alšie označenia $\mathrm{v}$ arabčine a indickom jazyku, ktoré sú pre nás zaujímavé z perspektívy vztahu rytmu a scénického umenia. Sú to arabské „máqam“ a indické „tal“, ktoré označujú periodicky sa opakujúce vzorce (patterns). Tieto vzorce sú pre nás dôležité, pretože človek má schopnost' rozoznat' ich v rôznych činnostiach, dokonca dokáže z nich mat' pôžitok.

\footnotetext{
${ }^{31}$ NUSKA, B. Rytmus, tvorba, divadlo. I díl. Praha : Pražská scéna, 2013, s. 49.

${ }^{32}$ Tamže, s. 50.

${ }^{33}$ Tamže, s. 55.

${ }^{34}$ Tamže, s. 57.

35 Tamže, s. 61.
} 
Schopnost’ vnímat’ a prežívat' rytmus sa javí ako biologicky daná predispozícia existencie života. Nachádza sa totiž v každej živej a neživej časti prírody, v každej časti doposial' vnímaného sveta. Rytmicky sa pohybujú vesmírne telesá, čierne diery, svetlo a všetka hmota vo vesmíre. Rytmus sa týka i našej planéty, ked’že tá obieha okolo vlastnej osi aj okolo Slnka. Rytmus sa nachádza v l'udskom tele nielen v podobe tlkotu srdca, dýchania a iných cyklicky sa opakujúcich základných funkcií organizmu, ale aj v našej nervovej sústave, hlasivkách, pohybe, emóciách. Rytmus existuje v bunkách v podobe pohybu častíc, ktoré oscilujú okolo jadra, dokonca je možné rozpoznat rytmus vo vibráciách týchto častíc, pretože oplývajú vlastnou točivostou. S rytmom sa spájajú d’alšie vlastnosti ako tempo, pulzácia, oscilácia, vibrácia, rotácia okolo vlastnej osi, obiehanie, vlastný mechanický moment častice, ale aj periodickost', cyklickost' a návratnost', resp. zvratnost'. Rozlišujeme rytmus vonkajší a vnútorný, vedomý a nevedomý, rytmy abiotické (pohyby vesmírnych telies a pohyby bunkových častíc), rytmy biotické (tie, ktoré bezprostredne súvisia s človekom, napr. biorytmy) atd'.

V aktivite vedomej l’udskej činnosti rozoznávame rytmus vo zvykoch, tradíciách, ornamentoch, stereotypoch, hudbe, tanci, reči, speve a umení vôbec, ale aj v matematike, fyzike, psychológii, ekonómii, histórii a pod. Už v nevedomých ludských činnostiach rozoznávame rytmické vzorce zakódované v emočnej pamäti a tiež dedičné („predprogramované“) základné rytmizované vzorce a štruktúry, rozvíjaním ktorých sa formuje napr. inteligencia. Český divadelný teoretik Alexej Pernica v tejto súvislostí tvrdí: „Ďalším rysom živých organizmov je proces diferenciácie ich pôvodne spontánnych činností v podobe reflexov. Tie z nich, ktoré neodumierajú a nezostávajú nemenné, sú schopné rozvíjat' sa učením a vytvárat asimilačné schémy. Práve rytmické štruktúry v nich tvoria jeden zo základov rozumového vývoja dietata do obdobia zhruba dvoch rokov. V neskorších úrovniach - od dvoch do pätnástich rokov, ked’ sú už zaznamenávané predstavy u dietat’a, prekrýva rytmické štruktúry zvnútornená alebo operačná zvratnoste."36

Popri tom, že je rytmus organickou súčastou života na našej planéte, je dôležité uvedomit’ si, z akých častí sa skladá, ked’že dráma aj scénické umenie sú vo svojich formách, štruktúrach a zložkách založené na opakovaní tohto princípu: „Na základe sledovania elektromagnetických vín príslušných nervových systémov bola zachytená neustála celostná rytmická činnost’ prebiehajúca v každom organizme. Tento nepretržitý sled istých ,napätí a uvol’není prebieha bez ohl'adu na to, ako aktívne alebo pasívne sa organizmus javí navonok prípadnému pozorovatelovi. Preto sa stáva pre celú živú prírodu základnou rytmickou schémou pravidelné striedanie napätia a uvol'nenia. Preto ked' sa kedykol'vek stretneme s akoukolvvek rytmickou štruktúrou, stretávame sa tiež s pôvodným rytmickým základom. Následkom toho môže naša emočná skúsenost', spoločne s rytmickou činnostou v nás posilňovat’ vedomie celostnosti rytmicky prežívaných javov. “37

Aby sme pochopili, akým spôsobom sa dá vnímat’ rytmické cítenie ako estetická funkcia, je potrebné zamerat sa na to, akým spôsobom divák aktivizuje kognitívne schopnosti v priebehu predstavenia. Človek do procesu poznávania vecí a javov najčastejšie zapája pocitovanie a vnímanie. Pocitovanie je rozpoznávanie impulzov

\footnotetext{
${ }^{36}$ PERNICA, A. Mýtové kořeny dramatických postav. Brno : Janáčkova akademie múzických umění, 2013, s. 13.

${ }^{37}$ Tamže.
} 
z prostredia prostredníctvom zmyslov (zraku, sluchu, hmatu, čuchu a chuti), ktoré vyvolávajú reakciu v organizme človeka - pocit. Ten je dôkladnou, celostnou a prvotnou informáciou o podnete z prostredia. Táto prvotná informácia je následne podrobená vnímaniu.

Domnievame sa, že schopnost’ dekódovat’ rytmické štruktúry v predstavení je záležitostou primárneho a najjednoduchšieho poznávacieho procesu - pocitovania. Pocitovanie je tým pádom inštinktívna danost̉, pretože sa týka výhradne zmyslového vnímania človeka. Schopnost’ rozoznávat’ rytmus sa realizuje prostredníctvom inštinktívnych, "predprogramovaných“ biologických schopností každého človeka. Účinok je v tomto prípade vyvolaný z emočných centier percipienta. Rozdiel medzi katarzným účinkom a účinkom, ktorý vyvoláva rytmus, spočíva v tom, že vo chvíli, ked' receptory zaznamenajú isté frekvencie rytmických štruktúr, ktoré človeku spôsobujú slast', pôsobia na neho práve v konkrétnom okamihu - tu a teraz, v čase, ked' je rozpoznaná rytmická štruktúra pomocou analyzátorov a tie automaticky vyvolajú reakciu. Vel'mi jednoducho si možno predstavit’ tento efekt napríklad v hudbe moment, ked’ pri počúvaní kvalitnej hudby človeku prebehne po chrbte mráz alebo dostane zimomriavky. Na druhej strane, katarzný účinok vyvolaný prostredníctvom empatie je produktom vnímania scénického diela ako celku. Toto vnímanie v sebe zahŕňa čiastkové vnemy a pocity, ktoré percipient vyhodnocuje v rámci svojich predošlých skúseností. Katarzný účinok vyvolaný prostredníctvom empatie je skôr individuálnou záležitostou, ked’že vo vel'kej miere závisí od emocionálneho vývoja jedinca a jeho individuálnych skúseností, ktoré počas svojej existencie nadobudol a na základe ktorých môže predvádzaný dej vyhodnotit’ a vztiahnut’ k osobným emocionálnym zážitkom.

Schopnost’ rozpoznat’ rytmické štruktúry a pocitovat’ pôžitok z účinku rytmu na l'udský organizmus sa javí nielen ako genetická predispozícia l'udskej prirodzenosti, ale aj sám človek rytmus počas svojho života vytvára, či už na vedomej alebo nevedomej úrovni. Rytmizáciu využíva a od prvopočiatku s ňou pracuje aj scénické umenie. V prvom rade hovoríme o forme rytmu nachádzajúcej sa v celkovej organizácii diela. Použijúc formuláciu Patricea Pavisa, „Všetky rozličné rytmy scénických systémov predstavenia (ktorých výslednica vytvára inscenáciu) sa dajú prečítat iba vnútri rámca fabuly. Rytmus napĺn̆a vlastnú funkciu, ked’ štruktúruje čas na epizódy, repliky, série monológov alebo stichomýtií, na striedanie výstupov. “38 Táto organizácia sekvencií môže prebiehat’ v dvoch rovinách - v textovej rovine, čiže v dráme, a v rovine scénickej, čiže v predstavení. V rovine textovej predlohy sa v procese vývoja dejín divadla vyvinula a v západnej kultúre etablovala predovšetkým štruktúra usporiadania drámy, ktorú definoval Aristoteles (tzv. Aristotelova krivka deja). Vo východnej kultúre sa v rovine scénickej interpretácie primárne pracuje rytmickou formou Džo-ha-kjú, formulovanou Zeamim. V tejto rytmickej štruktúre reflektujeme živý zdroj rituality, ktorý sa zo západného divadla vytráca.

Rytmické cítenie v scénickom diele sa javí byt̉ jednou z perspektív prenikania rituálnych vplyvov, ktorá sa začala počiatkom 20. storočia implementovat’ do inscenačných postupov a hereckých techník scénického umenia západnej kultúry. Dôvodom, prečo sa práve uvedená estetická funkcia v tomto období objavuje a znovu začleňuje

${ }^{38}$ PAVIS, P. Divadelný slovník. Bratislava : Divadelný ústav, 2004, s. 367. 
do experimentov divadelnej tvorby, je potreba, aby scénické dielo pôsobilo nielen na individuálnu percepciu diváka, ale aby vyvolalo spoločný zážitok prostredníctvom kolektívne zdiel'anej udalosti.

V období postmodernej konzumnej spoločnosti zdôrazňujúcej racionalizáciu sveta, v ktorej je uprednostňovaná predovšetkým individualita jedinca, paradoxne čelíme kríze identity jedinca a spoločnosti. Tá sa objavuje vo všetkých aspektoch života, vrátane scénického umenia, a hl'adá spôsob, akým by bolo možné tento stav zvrátit'. Ako tvrdí Nuska: „Prostredníctvom návratnosti opakujúcich sa udalostí, fiest, slávností a sviatkov, akoby sa realizoval aj starý mýtus Večného návratu, ono Vel'ké opakovanie - cyklické návraty, kedy jednotlivec, ale aj celé spoločenstvo nachvílu pocítia závan blaženého ,bezčasia', a zároveň sa človek a celé spoločnosti onými ritualizovanými udalostami istým spôsobom seba-identifikujú. L’udia si vd’aka nim uvedomujú: áno, sme, doposial’ tu ostávame, my trváme!“39

Schopnost' nielen precítit', ale aj vytvárat’ rytmus v rôznych vedomých aj nevedomých aktivitách človeka sa javí byt jedným z možných východísk z krízy, a zároveň spôsobom, akým je možné kolektívny zážitok realizovat’ a prinavrátit túto funkciu scénickému umeniu západnej kultúry.

\section{RHYTHMIC FEELING IN PERFORMANCE WORK.}

The Aesthetic and Non-aesthetic Function of Performance Art Based on the Ritual Nature of Theatre and Mythological Sources of Drama in the Early 20th Century

\section{Petra KOVALČÍKOVÁ}

The study focuses on the penetration of ritual elements into contemporary performance art. Reflection of the discussed topics focuses on the period of modernism and postmodernism in a Western cultural context, while the documentation of phenomena is based primarily on the theatrical experiments of the creators of the first and second theatrical reforms.

Text vznikol v rámci doktorandského štúdia na Fakulte dramatických umení Akadémie umení v Banskej Bystrici, školitel' Jan Vedral.

\section{LITERATÚRA:}

BOGART, Anne - LANDAU, Tina. Úhly pohledu. Praha : Divadelní ústav : Divadlo Archa, 2007. 205 s. ISBN 978-80-7008-210-2.

BRAUN, Kazimierz. Druhá divadelní reforma? Praha : Divadelní ústav, 1993. 171 s. ISBN 80-7008037-X.

BUDIL, Ivo T. Mýtus, jazyk a kulturní antropologie. Praha : Triton, 2003, 487 s. ISBN 80-7254-321-0. FREUD, Sigmund. Totem a tabu. Bratislava : Európa, 2015, 168 s. ISBN 978-80-89666-16-4.

${ }^{39}$ NUSKA, B. Rytmus, tvorba, divadla, I díl. Praha : Pražská scéna, 2013, s. 118. 
FÜRSTOVÁ, Mária - TRINKS, Jürgen. Filozofia. Bratislava : MEDIA TRADE, spol. s.r.o., 317 s. ISBN 80-08-02744-4.

JUNG, Carl Gustav - KERÉNYI, Karl. Věda o mytológii. Brno : Nakladatelství Tomáše Janečka, 1995. 231 s. ISBN 80-85880-06-7.

KAŠČÁK, Ondrej. Význam a miesto rituálov v pedagogickej teórii a praxi. In Pedagogická orientace, 2009, roč. 19, č. 2, s. $38-52$. ISSN 1211-4669.

KOSTER, Jan. Ritual performance and the politics of identity. [online]. [cit. 10. 2. 2019]. Dostupné na internete: http://www.let.rug.nl/koster/papers/JHP.Koster2.Edit.pdf.

LEHMANN, Hans-Thies. Postdramatické divadlo. Bratislava : Divadelný ústav, 2007. 355 s. ISBN 978-80-88987-81-9.

LÉVI-STRAUSS, Claude. Mýtus a význam. Bratislava : Archa, 1993. 56 s. ISBN 80-7115-052-5.

MAY, Rollo. Túžba po mýtoch. Bratislava : IKAR, 2007. 293 s. ISBN 978-80-551-13378-4.

MORIN, Edgar. Věda a svědomí. Brno : Atlantis, 1995. 133 s. ISBN 80-7108-108-6.

NUSKA, Bohumil. Rytmus, tvorba, divadlo, I. díl. Praha : Pražská scéna, 2013. 198 s. ISBN 97880-86102-76-4.

PAVIS, Patrice. Divadelný slovník. Bratislava : Divadelný ústav, 2004. 542 s. ISBN 80-88987-24-5.

PERNICA, Alexej. Mýtové kořeny dramatických postav. Brno : Janáčkova akademie múzických umění. 70 s. ISBN 80-85429-75-6.

RUMÁNEK, Ivan. Japonská dráma nó. Žáner vo vývoji. Bratislava : Veda, 2010. 459 s. ISBN 97880-224-1148-6.

SCHECHNER, Richard. Performancie, teórie, praktiky. Bratislava : Divadelný ústav, 2009, $341 \mathrm{~s}$. ISBN 978-80-89369-11-9.

SCHECHNER, Richard. Performance Theory. London : Routledge, 2003, 407 s. ISBN 0-203-44047-1

VAŠAŠOVÁ, Zlata. Tvorivá osobnost’ a kognitívne procesy. In Človek v spoločnosti, 1. čast' : Človek v edukačnom prostredí. Banská Bystrica : Univerzita Mateja Bela, 2007, s. 140 - 161. ISBN 978-80-8083-423-4.

WELSCH, Wolfgang. Naše postmoderní moderna. Praha : Zvon, 1994. 197 s. ISBN 80-7113-104-0.

ZICH, Otakar. Estetika dramatického umění. Praha : Panorama, 1986. 403 s.

Petra Kovalčíková

Fakulta dramatických umení AU

Horná 95

97401 Banská Bystrica

e-mail: pkovalcikova@gmail.com 